оценивания компетенций, критерии и показатели их сформированности, определен диагностический инструментарий. Каждая компетенция формально подразделяется (так как формирование и проявление структурных составляющих происходит в совокупности) на знания, умения, владения, которые систематически оцениваются на протяжении периода обучения. Учет набранных студентом баллов с их автоматическим подсчетом лучше проводить посредством использования специального программного обеспечения (например, модуль «электронные ведомости», информационной системы вуза).

Обозначенные выше сложности создают противоречие между устоявшейся моделью организации образовательного процесса ориентированного, в первую очередь, на формирование «готовности» к профессиональной деятельности, оценивание знаний, и необходимостью формирования компетентного специалиста с наличием профессионального опыта и необходимостью оценивания компетенций.

$$
\text { *** }
$$

1. Асадуллин Р. М., Васильев Л. И. Проблемы трансформации методологических принципов организации образовательного процесса в вузе /Сибирский педагогический журнал. Научное периодическое издание / №3, 2012: Новосибирск. 283 с.

2. Концепция Федеральной целевой программы развития образования на 2016 - 2020 годы № 2765-р, от 29 декабря 2014 года

\title{
Сманов И.С. \\ Использование произведений отечественной живописи в процессе организации воспитательной работы в школе
}

doi 10.18411/spc-04-12-2017-14

(Республика Казахстан, Шымкент)

idsp 000001:spc-04-12-2017-14

Общение с миром через художественный образ - так нам представляется педагогическое решение проблемы интеграции искусства и воспитания. И чем непосредственнее, естественнее, ярче, проще будет такое общение, тем естественнее и легче педагог достигнет воспитательной цели. Изобразительное искусство в силу своей специфики занимает особое место в системе использования искусства в воспитании детей. Его особенность, с точки зрения педагогической, заключается в наглядности, «материализованности» созданного автором художественного образа. Произведения живописи служат тем наглядным средством, благодаря которому будет происходить у детей переход от конкретно-предметного мышления к логическому. Поэтому мы полагаем, что именно обращению к произведениям живописи необходимо придавать особое значение в системе воспитательной работы школы.

Практика свидетельствует, что наиболее эффективным способом освоения отечественной художественной культуры и формирования эстетических и идейнонравственных представлений детей является систематизированное изучение на уроках изобразительного искусства творческого наследия казахстанских художников. Использование в эстетическом воспитании школьников дидактических возможностей национального своеобразия отечественного изобразительного искусства благотворно влияет на формирование художественного вкуса учащихся, их эстетического отношения к окружающей действительности, развивает этническое самосознание подрастающего поколения.

Методологическая новизна проведенного нами исследования состоит в максимально плодотворном и эффективном использовании в педагогическом процессе нравственно-эстетического воспитания и художественного образования школьников специфики самобытного профессионального творчества казахстанских художников, 
являющегося гармоничным сочетанием локальных художественных особенностей с прогрессивными традициями мировой культуры. Традиционная методика знакомства школьников с произведениями живописи, обеспечивающая эффективный уровень нравственного и эстетического воспитания подрастающего поколения, способствует формированию гармонически развитой личности. Такой результат достигается благодаря обобщению передового педагогического опыта, всестороннему изучению наиболее важных и сложных проблем теории нравственно-эстетического воспитания и художественного образования школьников средствами изобразительного искусства.

Обоснование представленной в данной статье концепции базировалось на изучении научных трудов дидактов, анализе и творческой переработке соответствующей дидактической и методической литературы, сборников научных статей и сообщений, а также на основе практического опыта преподавателей общеобразовательных учебных заведений ЮКО.В ходе систематизации материала о новых формах и условиях нравственно-эстетического развития учащихся средствами произведений изобразительного искусства использованы научные труды видных ученых: В.А.Балашова[1], Н.И. Болдырева [2], В.Е.Громова[3], Б.Т. Лихачева [4]. Нравственно-эстетическое воспитание рассматривается названными авторами не только как средство, необходимое для адекватного отношения детей к искусству и действительности, но и как способ формирования моральных качеств, расширения знаний учащихся о мире общества и природы.

Произведения живописи, являющиеся незаменимой школой эстетического воспитания, влияют на формирование таких качеств, как трудолюбие, уважительное отношение к старшим, доброта к детям, гостеприимство. Эти черты необходимо перенять у народной педагогической практики, поскольку именно они наиболее ярко выражены в произведениях мастеров отечественной живописи.

Анализируя современный научный опыт решения педагогических проблем художественного и эстетического воспитания школьников в образовательной системе разных стран, необходимо отметить следующие закономерности:

- стремление к практической направленности детских живописных произведений и художественных поделок, выполненных на интегрированных уроках труда и изобразительного искусства;

- освоение и широкое использование учащимися на уроках изобразительного искусства разнообразных художественных материалов - акварельных и гуашевых красок, пастели, мела, угля, тонированной бумаги;

- фоновое использование или непосредственное прослушивание на уроках изобразительного искусства музыкальных фрагментов, соответствующих по своему содержанию тематике живописных произведений учащихся;

- применение в процессе обучения изобразительному искусству специальных приемов и упражнений, направленных на развитие у школьников пространственных представлений, воображения, цветоощущения (например, используемой в японских школах системы по развитию цветоощущения, включающей серию таблиц, наглядных пособий, ряд конкретных учебных заданий).

Отечественная методика обучения школьников изобразительному искусству оказывает существенное влияние на высокий уровень нравственного и эстетического воспитания школьников, способствуя их общему развитию, успешно выполняя задачи гармонического развития личности. Подтверждением значимости проблем теории воспитания и обучения школьников средствами изобразительного искусства, обобщения передового педагогического опыта и совершенствования учебновоспитательного процесса служит постоянный исследовательский интерес к теории обучения и воспитания школьников средствами изобразительного искусства. 
Важным методическим положением использования изобразительного искусства в познавательном процессе является необходимость комплексного решения обучающих, воспитательных и образовательных задач: формирование понятийного уровня, становление мировоззрения, эстетическое и нравственное воспитание школьников, развитие их творческих способностей путем формирования определенных творческих умений и навыков. Художественное образование - процесс освоения школьниками совокупности знаний, умений навыков, формирования мировоззренческих установок в области искусства и художественного творчества.

Однако наряду с успехами современного подхода к образованию приходится отмечать, что в системе эстетического воспитания школьников, в процессе обучения их изобразительному искусству имеется ряд существенных недостатков, отрицательно сказывающихся на общем уровне эстетического развития школьников. Так, результаты педагогического исследования и детального анализа уровня преподавания предметов эстетического цикла в ряде школ республики выявили наличие пробелов в художественном образовании и эстетическом воспитании учащихся 5-8 классов:

- отсутствие научной, учебной и методической литературы, направленной на осуществление систематизированного художественно-эстетического воспитания с использованием творческого потенциала казахстанских художников;

- однообразие форм обучения и методики преподавания предметов эстетического цикла, снижающее познавательную и эстетическую активность школьников в учебной деятельности;

- описательно-повествовательный характер уроков-бесед по изобразительному искусству, превращающих репродукции выдающихся художников прошлого и современности лишь в наглядное пособие для поверхностного изучения (при этом игнорируются художественные достоинства, выразительные средства произведений, что не содействует, а препятствует развитию эстетического восприятия и художественного вкуса учащихся);

- недостаточная информированность и отсутствие интереса к творческому наследию мастеров отечественного профессионального изобразительного искусства и др.

Анализируя методы обучения и художественно-эстетического воспитания школьников, мы приходим к выводу, что основой образования всегда было изучение и обобщение передового педагогического опыта, всестороннее освоение творческого наследия художников предыдущих поколений. Этот теоретический анализ рассматриваемой проблемы дает возможность для подробного изучения и использования профессионального изобразительного искусства в художественноэстетическом воспитании казахстанских школьников. Среди различных направлений воспитательной работы в школе особое значение, как уже было доказано выше, приобретает задача нравственно-эстетического становления школьников.

В современных условиях гуманизации общества становятся актуальными предметы художественно-эстетического цикла, оказывающие значительное влияние на воспитание гармонически развитой, творческой личности. Усиление значимости художественно-эстетического образования способствует приобщению школьников к изучению отечественной живописи. Но задача нравственно-эстетического воспитания заключается не только в освоении художественного опыта, но и в развитии творческих способностей школьников, в формировании у них стремления к эстетическому восприятию действительности, утверждение ценностных ориентаций личности, идеалов красоты окружающего мира.

Важным фактором эффективного художественно-эстетического образования казахстанских школьников является обращение к изучению на уроках локальных 
особенностей профессионального изобразительного искусства Казахстана, что способствует не только развитию художественного вкуса и познавательных интересов учащихся, но и формированию их этнического самосознания, чувства сопричастности со своим народом и его культурой.

$$
* * *
$$

1. Балашов В.А. Вопросы эстетического воспитания и эстетики// Учебное пособие. - М.,1968. -252 c.

2. Болдырев Н.И. Методика воспитательной работы в школе// Учебное пособие для пед. ин-тов. - М., 1974. $-223 \mathrm{c}$.

3. Громов В.Е. Художественная культура и гармоническое развитие личности. - Киев, 1982. -238 с.

4. Лихачев Б.Т. Теория эстетического воспитания школьников: учебное пособие по спецкурсу для студентов педагогических институтов. - М., 1985. - 176 с.

\section{Смольникова В.В., Ледовская Н.В. \\ Особенности организация самостоятельной работы с иностранными студентами в институте Нефти и Газа СКФУ}

Северо-Кавказский федеральный университет

(Россия, Ставрополь)

doi 10.18411/spc-04-12-2017-15

idsp 000001:spc-04-12-2017-15

В стенах Северо-Кавказского федерального университета обучается около полторы тысячи граждан из 59 стран мира. 90\% из них ежедневно приходят в учебные аудитории, это почти десятая часть всех очников университета.на момент создания федерального вуза в нем насчитывалось 182 обучающихся из 12 зарубежных государств.Как видим, сегодня ситуация изменилась, количество зарубежных студентов выросло почти в 10 раз.

Каждый третий студент Института нефти и газа приехал из Европы, Азии или Африки. И естественно, что они испытывают сложности включения в новую языковую и социокультурную среду. Как показали опросы студентов, одной из насущных проблем является знание русского языка в учебной ситуации[1], поэтому учебная работа с иностранными студентами приобретает свою специфику.

В рамках Концепция развития современного образования наиболее востребовано самообразование, опирающееся на самостоятельный поиск необходимых знаний. Это обеспечивает не только реализацию требований Федеральных государственных стандартов высшего профессионального образования, но и позволяет сформировать у студента потребность к самообучению и саморазвитию, возможность реализации своего личностного потенциала[2].

Самостоятельная работа - один из видов планируемой деятельности студентов, которая выполняетсяво внеаудиторное время. Такая работа может и должна проводиться студентом самостоятельно, без участия преподавателя, но при его методическом руководстве,что особенно важно для иностранных студентов.

Среди существующих форм самостоятельной работы, по нашему опыту,наиболее эффективным являетсясоставление плана-конспекта по заданной теме. Из аудиторных работ - самостоятельное решение типовых задач.

Составление плана-конспекта по заданной преподавателем теме проводиться на базе рекомендованной литературы (включая информационные образовательные ресурсы), а так же при подготовке к лабораторным и практическим занятиям.Для облегчения работы с литературой в рамках поэтапного раскрытия темы студентам предлагается ответить на ряд поставленных вопросов. На первом этапе работы с темой по предложенным вопросам студент выбирает краткие ответы из теоретического обоснования соответствующей лабораторной работы или практического занятия. Затем, учащемуся предлагается дополнить выписанные краткие ответы информацией из 